\title{
Effects of Starvation in Rock Bream, Oplegnathus fasciatus and Olive Flounder, Paralichthys olivaceus
}

\author{
${ }^{\dagger}$ In-Seok Park ${ }^{1}$, Hyun Woo Gil ${ }^{1}$, Gwang Yeol Yoo $^{2}$ and Ji Su Oh${ }^{1}$ \\ ${ }^{1}$ Division of Marine Bioscience, College of Ocean Science and Technology, \\ Korea Maritime and Ocean University, Busan 606-791, Korea \\ ${ }^{2}$ The Province of Chungcheongnam-do Fisheries Research Institute, Boryeng 355-851, Korea
}

\begin{abstract}
We assessed the effects of various dietary conditions on the growth, phenotypic traits, and morphometric dimensions of rock bream, Oplegnathus fasciatus and on the morphometric dimensions of sectioned olive flounder, Paralichthys olivaceus. Rock bream in the fed group increased in body weight, standard length, and condition factor, but these parameters decreased significantly for fish in the starved group $(P<0.05)$. The head connection dimensions of fish in the fed group decreased, while for starved fish there was increase in external morphometric dimensions $(P<0.05)$. In both species, sectioned morphometric analysis revealed that fish in the fed group had a larger body circumference and cross-cut sectional area, and greater cross-cut section height, relative to the starved group $(P<0.05)$.
\end{abstract}

Key words : Morphometric dimension, Olive flounder, Phenotypic trait, Rock bream, Starvation

\section{INTRODUCTION}

Many species of fish undergo periods of natural starvation because of temperature declines associated with seasonal changes, spawning migration, and regional and seasonal decreases in food supply. To survive periods of starvation fish use biochemical, physiological, and behavioral strategies, in addition to using stored endogenous energy derived from basic metabolic processes (Mustafa \& Mittal, 1982; Weatherley \& Gill, 1987; Lee et al., 1999; Park et al., 2002, 2007; Hur et al., 2006a, 2006b; Park, 2006). However, this survival strategy leaves little energy for other biological functions, including somatic growth. As a result, growth in body size slows considerably during starvation. From a commercial perspective, traits including size, weight and sectioned body parameters are important because they control the value of the product (Gjerde, 1989; Gjerde \& Schaeffer, 1989; Park et al., 2002).

Although the body shape of fish is largely determined by genetic factors (Riddell et al., 1981; Taylor \& McPhail, 1985), the use of morphometric analysis to discriminate among genetically discrete groups within a single fish species is limited by the difficulty of measuring environmentally induced variations in body shape (Ihssen et al., 1981; Currens et al., 1989; Park et al., 2001). Consequently, understanding how morphometric characteristics are affected by various feeding regimens will improve assessment of genetically discrete groups within the same species in habitats where

\footnotetext{
Manuscript received 11 May 2015, Received in revised form 28 May 2015, Accepted 9 June 2015

${ }^{\dagger}$ Corresponding Author : In-Seok Park, Division of Marine Bioscience, College of Ocean Science and Technology, Korea Maritime and Ocean University, Busan 606-791, Korea. Tel. : +82-51-410-4321, Fax : +82-51-405-4322, E-mail : ispark@kmou.ac.kr

This is an Open Access article distributed under the terms of the Creative Commons Attribution Non-Commercial License (http:// creativecommons.org/licenses/by-nc/3.0) which permits unrestricted non-commercial use, distribution, and reproduction in any medium, provided the original work is properly cited.
} 
food abundance and quality differ (Currens et al., 1989).

Both truss and classical dimensions are used to describe fish body shape (Hubbs \& Lagler, 1947; Straler, 1947). Truss dimensions, which include components of body depth and length along the longitudinal axis, have theoretical advantages over classical morphometric characters in discriminating among groups (Humphries et al., 1981; Straüss \& Bookstein, 1982; Winans, 1984; Currens et al., 1989). A variety of characteristics of the sectioned surface are critical elements in the marketing of fish because of consumer preferences with respect to the size and shape of the sectioned surface in gutted, sectioned, smoked, and non-gutted fish (Gjerde, 1989; Gjerde \& Schaeffer, 1989; Park et al., 2002).

Rock bream, Oplegnathus fasciatus, is a marine fish that occurs in rocky areas of shallow coastal regions, and is distributed in these habitats in the marine environments of Korea, Japan, Taiwan, and Hawaii (Choi et al., 2002). To meet the demand for this high-quality popular fish in Korea rock bream are raised in aquaculture facilities along the south coast at Tongyeong, Geoje, Namhae, and Yeosu. As suggested by its flattened oval body, olive flounder, Paralichthys olivaceus, is a bottom dwelling fish; it mainly occurs on the benthos at depths of 10-20 m. The species is widely distributed in Korea and East Asia (Choi et al., 2002). The olive flounder has a flattened oval body, and mainly occurs in the benthos at depths of 10 to $200 \mathrm{~m}$, with a wide distribution in Korea and East Asia. Approximately 40,922 tonnes of this species were produced in Korea in 2010 (Park et al., 2012). The olive flounder may experience shortor long-term starvation, e.g., directly when feeding is arrested, or indirectly because of low water temperatures when cold water masses move into their habitat or during red tides in the warm summer season in Korea (Park et al., 2012).

In previous study of rock bream's starvation, effects of starvation on kidney melano-macrophage centre in subadult and growth and development of larval and juvenile have been reported (Seol et al., 2009; Sun et al., 2009).
The effects of starvation on growth, phenotypic traits, morphometric characteristics and histological change of hepatocyte and intestinal epithelium in olive flounder have been reported (Park, 2006; Park et al., 2006, 2007). But similar studies between olive flounder and rock bream have not been undertaken. Therefore, in this study we investigated the effects of starvation on growth, phenotypic traits and morphometric characteristics in rock bream, and also determined the effects of starvation on sectioned morphometric characteristics in both olive flounder and rock bream.

\section{MATERIALS AND METHODS}

\section{Experimental fish}

In July 2011, specimens of rock bream, Oplegnathus fasciatus (SL, standard length $\pm \mathrm{SD}$ : $15.86 \pm 0.75 \mathrm{~cm}$; BW, body weight \pm SD: $164.7 \pm 32.21 \mathrm{~g}$ ), and olive flounder, Paralichthys olivaceus ( $\mathrm{SL} \pm \mathrm{SD}: 16.6 \pm 0.45 \mathrm{~cm} ; \mathrm{BW} \pm \mathrm{SD}: 100.7 \pm 11.67 \mathrm{~g}$ ), were obtained from the Gyeongsangnam-do Fisheries Resources Research Institute, Korea. The fish were transported to the Fishery Genetics and Breeding Science Laboratory of the Korea Maritime University, Korea, and reared in a recirculating culture system. Feeding and starvation experiments began in July 2011 (rock bream) and October 2011 (olive flounder), and were terminated after eight and twelve weeks, respectively, when the fish began to exhibit obvious distress from fasting.

Three experimental groups were established; initial control, fed and starved. For two weeks prior to commencement of each experiment the fish were fed daily with commercial feed (E-Wha Oil \& Fat Ind. Co. Ltd, Busan, Korea; 50\% crude protein, $8 \%$ crude fat, $4 \%$ crude fiber and $15 \%$ ash) at a rate of $1-3 \%$ of total BW. During the experiment the fed group was hand-fed three times daily at $4 \mathrm{~h}$ feeding intervals, while the starved group was fasted throughout the experiment. The experiments were conducted in a 
recirculating system consisting of 1.1 ton FRP circular tank (118 cm diameter $\times 100 \mathrm{~cm}$ depth). Each experimental treatment comprised two tanks, each containing 40 specimens. Light was provided by four $40 \mathrm{~W}$ fluorescent bulbs controlled by an electric timer, which maintained a $12 \mathrm{~h}: 12$ h light:dark cycle. No lights were used during the dark period. The water temperature was controlled automatically, and maintained at $22 \pm 0.6^{\circ} \mathrm{C}$ during the experimental period.

\section{Investigation of growth and phenotypic traits}

For the rock bream, 10 fish were removed from the fed and starved groups, respectively, and used for growth measurements and assessment of phenotypic traits. The SL and $\mathrm{BW}$ of each fish was measured to the nearest $0.01 \mathrm{~cm}$ using a digital vernier caliper (CD-20CP, Japan), and the BW of each fish was measured to the nearest $0.01 \mathrm{~g}$ using an electronic balance (JW-1, Korea). Fish were euthanized with an overdose of clove oil (Sigma, USA). The growth and phenotypic factors examined included growth rate for standard length (GRL), growth rate for body weight (GRW), SL, condition factor (CF), un-gutted BW, gutted body weight $(\mathrm{GW})$, viscera weight (VW), viscera index (VI), and dressing percentage (DP).

\section{External morphometric analysis}

For rock bream 20 fish were removed from the fed and starved groups for external morphometric analysis. The fish were euthanized with an overdose of clove oil and the length of each fish was measured as described above. Body outline measurements between landmarks were made for both truss (20 distances) and classical (11 distances) dimensions (Fig. 1 and Table 1). Each morphometric dimension was analyzed relative to the SL.

\section{Sectioned morphometric analysis}

For each of rock bream and olive flounder, a morphometric analysis of body sections was undertaken based on (a)

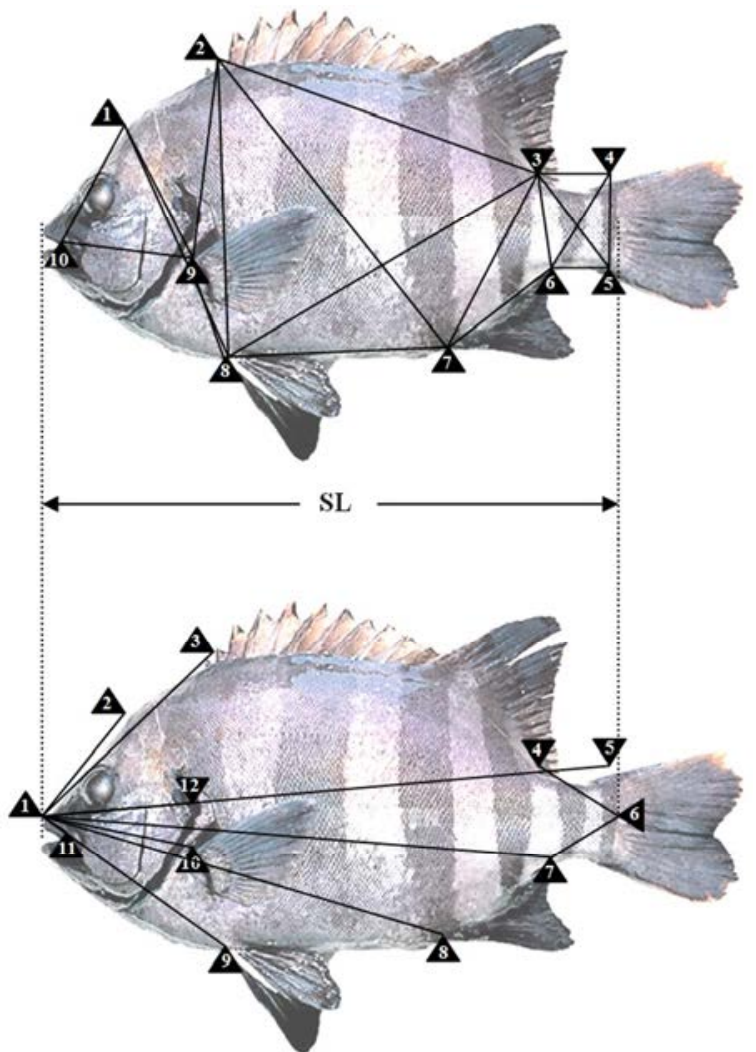

Fig. 1. Truss and classical dimensions for rock bream, Oplegnathus fasciatus in this starvation experiment. The morphological landmarks are numbered and the morphometric distances between landmarks are shown: (a) truss dimension; (b) classical dimension. SL, standard length.

10 and 30 fish sampled from the fed and starved groups, respectively. The experiment was carried out in triplicate. The length of each species was also measured to the nearest $0.01 \mathrm{~cm}$ using a digital vernier caliper (CD-20CP, Japan), and to the nearest $0.1 \mathrm{~cm}$ using an opisometer (Curvimeter, Japan). The width of each fish was measured using the grid method.

Fish were captured, euthanized with an overdose of clove oil (Sigma, USA), and sectioned along the $\mathrm{O}, \mathrm{A}$, and $\mathrm{M}$ lines shown in Figs. 2 and 3. The body morphometric dimensions examined (Figs. 2 and 3) were CIA (the circumference of the body at a right angle from the midpoint of the SL), CIO (the body circumference at one-third of the 
Table 1. Body shape dimensions in rock bream, Oplegnathus fasciatus

\begin{tabular}{|c|c|}
\hline \multicolumn{2}{|l|}{ Dimension } \\
\hline \multicolumn{2}{|l|}{ Truss dimension } \\
\hline Posterior end of supraocciptal - origin of dorsal fin & $1 \times 2$ \\
\hline Posterior end of supraocciptal - origin of pelvic fin & $1 \times 8$ \\
\hline Posterior end of supraocciptal - origin of pectoral fin & $1 \times 9$ \\
\hline Posterior end of supraocciptal - posterior end of maxillary & $1 \times 10$ \\
\hline Origin of dorsal fin - insertion of dorsal fin & $2 \times 3$ \\
\hline Origin of dorsal fin - origin of anal fin & $2 \times 7$ \\
\hline Origin of dorsal fin - origin of pelvic fin & $2 \times 8$ \\
\hline Origin of dorsal fin - origin of pectoral fin & $2 \times 9$ \\
\hline Insertion of dorsal fin - dorsal origin of caudal fin & $3 \times 4$ \\
\hline Insertion of dorsal fin - ventral origin of caudal fin & $3 \times 5$ \\
\hline Insertion of dorsal fin - insertion of anal fin & $3 \times 6$ \\
\hline Insertion of dorsal fin - origin of anal fin & $3 \times 7$ \\
\hline Insertion of dorsal fin - origin of pelvic fin & $3 \times 8$ \\
\hline Dorsal origin of caudal fin - ventral origin of caudal fin & $4 \times 5$ \\
\hline Dorsal origin of caudal fin - insertion of anal fin & $4 \times 6$ \\
\hline Ventral origin of caudal fin - insertion of anal fin & $5 \times 6$ \\
\hline Insertion of anal fin - origin of anal fin & $6 \times 7$ \\
\hline Origin of anal fin - origin of pelvic fin & $7 \times 8$ \\
\hline Origin of pelvic fin - origin of pectoral fin & $8 \times 9$ \\
\hline Origin of pectoral fin - posterior end of maxillary & $9 \times 10$ \\
\hline \multicolumn{2}{|l|}{$\begin{array}{ll}\text { Classical dimension } \\
\end{array}$} \\
\hline Most anterior extension of the head - posterior end of supraoccipital & $1 \times 2$ \\
\hline Most anterior extension of the head - origin of dorsal fin & $1 \times 3$ \\
\hline Most anterior extension of the head - dorsal origin of caudal fin & $1 \times 5$ \\
\hline Most anterior extension of the head - insertion of anal fin & $1 \times 7$ \\
\hline Most anterior extension of the head - origin of anal fin & $1 \times 8$ \\
\hline Most anterior extension of the head - origin of pelvic fin & $1 \times 9$ \\
\hline Most anterior extension of the head - origin of pectoral fin & $1 \times 10$ \\
\hline Most anterior extension of the head - posterior end of maxillary & $1 \times 11$ \\
\hline Most anterior extension of the head - most posterior aspect of operculum & $1 \times 12$ \\
\hline Insertion of dorsal fin - most posterior scale in lateral line & $4 \times 6$ \\
\hline Insertion of anal fin - most posterior scale in lateral line & $6 \times 7$ \\
\hline
\end{tabular}

Refer to landmarks of Fig. 1 for number of Table 1.

distance between the most posterior point of the operculum and the midpoint of the SL), CIM (the body circumference midway between the midpoint of the SL and the most posterior scale on the lateral line), AO (the area at one- 
third the distance between the most posterior point of the operculum and midpoint of the SL), AA (the area at a vertical line that intersects at right angles to the midpoint of the SL), AM (the area at the midpoint between the midpoint of the SL and most posterior scale on the lateral line), THO (the total height at one-third distance between the most posterior point of the operculum and the midpoint of the SL), THA (the total height at a vertical line intersecting at a right angle to the midpoint of the SL), THM (the total height at the midpoint between the midpoint of the SL and most posterior scale on the lateral line), WO (the width at one-third distance between the most posterior point of the operculum and the midpoint of the SL), WA
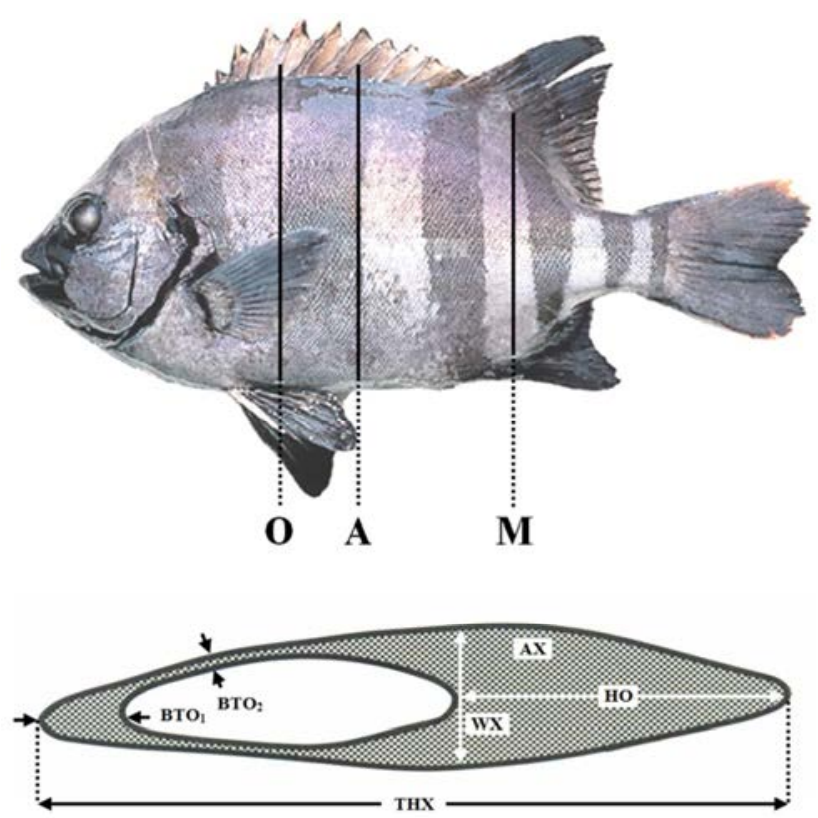

Fig. 2. Total height (THX), width (WX), area (AX), height (HO), and belly thickness $\left(\mathrm{BTO}_{1}\right.$ and $\left.\mathrm{BTO}_{2}\right)$ in rock bream, Oplegnathus fasciatus, measured on cross sectional slices made at one-third of the distance between the most posterior point of the operculum and the midpoint of the standard length $(X=0)$, at a vertical line that intersects at a right angle with the midpoint of the standard length $(X=A)$, and at a line at the midpoint between the midpoint of the standard length and most posterior scale on the lateral line $(\mathrm{X}=\mathrm{M})$. (the width at a vertical line that intersect at a right angle with the midpoint of the SL), WM (the width at the midpoint between the midpoint of the SL and most posterior scale on the lateral line), HO (the height at one-third distance between the most posterior point of the operculum and the midpoint of the SL), BTO 1 (belly thickness 1 at one-third distance between the most posterior point of the operculum and the midpoint of the SL), BTO 2 (belly thickness 2 at one-third distance between the most posterior point of the operculum and the midpoint of the SL), ABT (average belly thickness), BS (body shape), SS (section shape), Ratio 1 (fed/initial), Ratio 2 (starved/initial), and Ratio 3 (fed/starved).

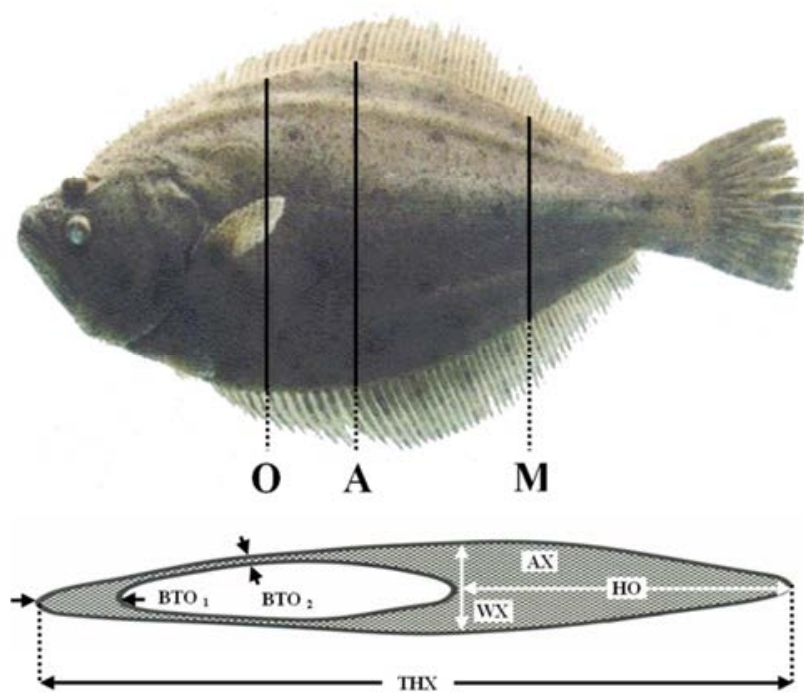

Fig. 3. Total height (THX), width (WX), area (AX), height (HO), and belly thickness $\left(\mathrm{BTO}_{1}\right.$ and $\left.\mathrm{BTO}_{2}\right)$ in olive flounder, Paralichthys olivaceus, measured on cross sectional slices made at one-third of the distance between the most posterior point of the operculum and the midpoint of the standard length $(X=0)$, at a vertical line that intersects at a right angle with the midpoint of the standard length $(\mathrm{X}=\mathrm{A})$, and at a line at the midpoint between the midpoint of the standard length and most posterior scale on the lateral line $(X=M)$. 


\section{Statistical analysis}

All experiments were performed in triplicate. The data were analyzed by one-way ANOVA using the SPSS statistical package (SPSS 9.0; SPSS Inc., USA). Means were separated using Duncan's multiple range test and were considered significantly different at $P<0.05$ (Duncan, 1955).

\section{RESULTS}

Table 2 shows the growth measurements and phenotypic traits for the fed and starved groups of rock bream, Oplegnathus fasciatus. The values for GRL and GRW were higher in the fed group than in the starved group $(P<0.05)$. For $\mathrm{CF}$, all three groups (fed, starved, and initial) were significantly different from each other $(P<0.05)$. The fed group was 1.15 -fold that of the initial group, the starved group was 0.85 -fold that of the initial group, and the fed group was 1.66-fold that of the starved group $(P<0.05)$. The values of GW, VW, and VI were highest for the fed group, and for DP were highest for the starved group $(P<0.05)$.
As shown in Table 3, the results of measurement of external morphometric dimensions for the fed and starved groups of rock bream revealed. There were significant differences in the truss dimensions between the fed and starved groups $(P<0.05)$. Relative to the initial group, for the fed group the values of $1 \times 2$ and $3 \times 8$ increased but those of $3 \times 4$ and $4 \times 6$ decreased, while for the starved group the values of $1 \times 2,1 \times 9,1 \times 10,4 \times 5,4 \times 6$, and $5 \times 6$ increased but those of $3 \times 8$ and $7 \times 8$ decreased $(P<0.05)$. There were no significant differences among the three feeding regimes for the truss dimensions $1 \times 8,2 \times 3,2 \times 7$, $2 \times 8,2 \times 9,3 \times 5,3 \times 6,3 \times 7$, and $6 \times 7(P>0.05)$. Significant differences were also found in the classical dimensions between the fed and starved groups $(P<0.05)$. Relative to the initial group, the values of $1 \times 5$ and $1 \times 9$ decreased in the fed group, whereas in the starved group the values of $1 \times 2,1 \times 3,1 \times 5,1 \times 10$, and $1 \times 12$ increased but that of $4 \times 6$ decreased $(P<0.05)$. The classical dimensions $1 \times 7,1 \times 8$, $1 \times 11$, and $6 \times 7$, did not differ significantly among the three feeding regimes $(P>0.05)$.

Table 2. Phenotypic traits of rock bream, Oplegnathus fasciatus after 8 weeks in initial, fed, and starved treatments

\begin{tabular}{ccccccc}
\hline \hline Trait & Initial group & Fed group & Starved group & Ratio 1 & Ratio 2 & Ratio 3 \\
\hline SL (cm) & $15.9 \pm 0.76^{\mathrm{a}}$ & $16.9 \pm 1.72^{\mathrm{a}}$ & $13.5 \pm 1.16^{\mathrm{b}}$ & 1.06 & 0.85 & 1.25 \\
BW (g) & $164.7 \pm 32.21^{\mathrm{b}}$ & $231.2 \pm 57.34^{\mathrm{a}}$ & $86.1 \pm 19.67^{\mathrm{c}}$ & 1.40 & 0.52 & 2.69 \\
GRL (\%) & - & $6.9 \pm 11.39^{\mathrm{a}}$ & $-15.1 \pm 6.17^{\mathrm{b}}$ & - & - & - \\
GRW (\%) & - & $46.0 \pm 5.13^{\mathrm{a}}$ & $-46.7 \pm 11.38^{\mathrm{b}}$ & - & - & - \\
CF & $4.1 \pm 0.71^{\mathrm{b}}$ & $4.7 \pm 0.50^{\mathrm{a}}$ & $3.5 \pm 0.27^{\mathrm{c}}$ & 1.15 & 0.85 & 1.34 \\
GW (g) & $139.3 \pm 28.17^{\mathrm{b}}$ & $193.2 \pm 5.28^{\mathrm{a}}$ & $85.2 \pm 9.23^{\mathrm{c}}$ & 1.39 & 0.61 & 2.27 \\
VW (g) & $17.0 \pm 6.87^{\mathrm{b}}$ & $27.9 \pm 7.33^{\mathrm{a}}$ & $5.8 \pm 1.15^{\mathrm{c}}$ & 1.64 & 0.34 & 4.81 \\
VI (\%) & $11.8 \pm 3.24^{\mathrm{b}}$ & $14.7 \pm 2.26^{\mathrm{a}}$ & $6.9 \pm 1.02^{\mathrm{c}}$ & 1.25 & 0.58 & 1.05 \\
DP (\%) & $89.5 \pm 2.58^{\mathrm{b}}$ & $87.2 \pm 1.67^{\mathrm{c}}$ & $93.6 \pm 0.89^{\mathrm{a}}$ & 0.97 & 2.13 & 0.93 \\
\hline
\end{tabular}

The values are means \pm SD $(n=10)$ of triplicate groups. In each row the means with the same superscript letter are not significantly different $(P>0.05)$. Abbreviation, SL: standard length; BW: body weight; GRL (growth rate for standard length; \%): (final mean SL-initial mean SL) ×100/initial mean SL; GRW (growth rate for BW; \%): (final mean BW-initial mean BW) $\times 100 /$ initial mean BW; CF: condition factor=un-gutted BW $\times 100 /$ standard length; GW: gutted body weight; VW: viscera weight; VI: viscera index $=($ viscera weight $/ \mathrm{GW}) \times 100 ; \mathrm{DP}$ : dressing percentage $=(\mathrm{GW} /$ un-gutted $\mathrm{BW}) \times 100 ; \mathrm{Ratio} 1$ : fed group/initial group; Ratio 2: starved group/initial group; Ratio 3: fed group/starved group. 
Table 3. Truss and classical dimensions of rock bream, Oplegnathus fasciatus after 8 weeks in initial, fed, and starved treatments

\begin{tabular}{|c|c|c|c|}
\hline Dimension & Initial group & Fed group & Starved group \\
\hline \multicolumn{4}{|c|}{ Truss dimension } \\
\hline $1 \times 2$ & $18.8 \pm 1.56^{\mathrm{b}}$ & $20.2 \pm 1.39^{\mathrm{ab}}$ & $20.8 \pm 2.08^{\mathrm{a}}$ \\
\hline $1 \times 8$ & $45.3 \pm 1.88^{\mathrm{a}}$ & $45.7 \pm 2.23^{\mathrm{a}}$ & $46.9 \pm 1.68^{\mathrm{a}}$ \\
\hline $1 \times 9$ & $27.9 \pm 1.32^{\mathrm{b}}$ & $28.4 \pm 1.80^{\mathrm{b}}$ & $29.9 \pm 1.29^{\mathrm{a}}$ \\
\hline $1 \times 10$ & $22.6 \pm 1.01^{\mathrm{b}}$ & $22.6 \pm 1.66^{\mathrm{b}}$ & $24.5 \pm 1.98^{\mathrm{a}}$ \\
\hline $2 \times 3$ & $58.6 \pm 2.40^{\mathrm{a}}$ & $58.3 \pm 2.34^{\mathrm{a}}$ & $59.1 \pm 1.50^{\mathrm{a}}$ \\
\hline $2 \times 7$ & $64.4 \pm 3.39^{\mathrm{a}}$ & $63.7 \pm 2.89^{\mathrm{a}}$ & $65.7 \pm 2.63^{\mathrm{a}}$ \\
\hline $2 \times 8$ & $50.3 \pm 2.65^{\mathrm{a}}$ & $50.9 \pm 2.15^{\mathrm{a}}$ & $51.2 \pm 2.06^{\mathrm{a}}$ \\
\hline $2 \times 9$ & $34.2 \pm 2.44^{\mathrm{a}}$ & $34.6 \pm 1.75^{\mathrm{a}}$ & $34.7 \pm 1.34^{\mathrm{a}}$ \\
\hline $3 \times 4$ & $11.6 \pm 0.99^{\mathrm{a}}$ & $9.0 \pm 0.84^{\mathrm{b}}$ & $11.9 \pm 1.20^{\mathrm{a}}$ \\
\hline $3 \times 5$ & $17.0 \pm 1.07^{\mathrm{a}}$ & $17.0 \pm 1.42^{\mathrm{a}}$ & $17.6 \pm 0.69^{\mathrm{a}}$ \\
\hline $3 \times 6$ & $15.6 \pm 0.65^{\mathrm{a}}$ & $16.1 \pm 0.95^{\mathrm{a}}$ & $15.7 \pm 0.82^{\mathrm{a}}$ \\
\hline $3 \times 7$ & $38.1 \pm 1.13^{\mathrm{a}}$ & $39.0 \pm 1.63^{\mathrm{a}}$ & $38.9 \pm 1.85^{\mathrm{a}}$ \\
\hline $3 \times 8$ & $57.1 \pm 1.15^{\mathrm{b}}$ & $60.0 \pm 2.59^{\mathrm{a}}$ & $54.9 \pm 2.23^{\mathrm{c}}$ \\
\hline $4 \times 5$ & $15.1 \pm 0.99^{\mathrm{b}}$ & $14.3 \pm 1.18^{\mathrm{b}}$ & $16.6 \pm 0.87^{\mathrm{a}}$ \\
\hline $4 \times 6$ & $18.9 \pm 1.50^{\mathrm{b}}$ & $17.5 \pm 1.51^{\mathrm{c}}$ & $20.5 \pm 1.25^{\mathrm{a}}$ \\
\hline $5 \times 6$ & $8.9 \pm 0.77^{\mathrm{b}}$ & $8.7 \pm 0.74^{\mathrm{b}}$ & $10.0 \pm 0.79^{\mathrm{a}}$ \\
\hline $6 \times 7$ & $26.2 \pm 1.74^{\mathrm{a}}$ & $26.6 \pm 2.56^{\mathrm{a}}$ & $26.6 \pm 1.54^{\mathrm{a}}$ \\
\hline $7 \times 8$ & $30.7 \pm 1.42^{\mathrm{a}}$ & $31.0 \pm 1.93^{\mathrm{a}}$ & $27.5 \pm 2.50^{\mathrm{b}}$ \\
\hline $8 \times 9$ & $18.8 \pm 0.90^{\mathrm{ab}}$ & $19.6 \pm 0.95^{\mathrm{a}}$ & $18.2 \pm 1.14^{\mathrm{b}}$ \\
\hline $9 \times 10$ & $23.9 \pm 1.12^{\mathrm{ab}}$ & $23.4 \pm 1.32^{\mathrm{b}}$ & $25.4 \pm 2.33^{\mathrm{a}}$ \\
\hline \multicolumn{4}{|c|}{ Classical dimension } \\
\hline $1 \times 2$ & $23.1 \pm 0.90^{\mathrm{ab}}$ & $22.1 \pm 2.45^{\mathrm{b}}$ & $24.6 \pm 2.25^{\mathrm{a}}$ \\
\hline $1 \times 3$ & $40.9 \pm 2.73^{b}$ & $42.2 \pm 2.40^{\mathrm{b}}$ & $45.0 \pm 2.55^{\mathrm{a}}$ \\
\hline $1 \times 5$ & $96.1 \pm 1.65^{\mathrm{b}}$ & $94.3 \pm 1.96^{\mathrm{c}}$ & $97.8 \pm 1.25^{\mathrm{a}}$ \\
\hline $1 \times 7$ & $87.6 \pm 3.54^{\mathrm{a}}$ & $86.3 \pm 3.39^{a}$ & $87.3 \pm 3.02^{\mathrm{a}}$ \\
\hline $1 \times 8$ & $70.7 \pm 2.49^{\mathrm{a}}$ & $68.4 \pm 3.34^{\mathrm{a}}$ & $70.1 \pm 2.93^{\mathrm{a}}$ \\
\hline $1 \times 9$ & $43.8 \pm 1.80^{\mathrm{a}}$ & $40.6 \pm 2.49^{b}$ & $43.9 \pm 2.11^{\mathrm{a}}$ \\
\hline $1 \times 10$ & $30.7 \pm 1.08^{\mathrm{b}}$ & $29.7 \pm 1.70^{\mathrm{b}}$ & $32.4 \pm 1.58^{\mathrm{a}}$ \\
\hline $1 \times 11$ & $8.7 \pm 0.56^{\mathrm{a}}$ & $8.3 \pm 1.14^{\mathrm{a}}$ & $8.4 \pm 0.82^{\mathrm{a}}$ \\
\hline $1 \times 12$ & $32.2 \pm 1.42^{\mathrm{b}}$ & $32.7 \pm 1.56^{\mathrm{b}}$ & $34.8 \pm 1.72^{\mathrm{a}}$ \\
\hline $4 \times 6$ & $17.1 \pm 1.01^{\mathrm{a}}$ & $16.1 \pm 1.72^{\mathrm{ab}}$ & $15.5 \pm 1.12^{\mathrm{b}}$ \\
\hline $6 \times 7$ & $16.7 \pm 1.34^{\mathrm{a}}$ & $16.8 \pm 0.98^{\mathrm{a}}$ & $16.8 \pm 0.92^{\mathrm{a}}$ \\
\hline
\end{tabular}

The values are means $\pm \mathrm{SD}(\mathrm{n}=20)$ of triplicate groups. In each row the means with the same superscript letter are not significantly different $(P>0.05)$. Refer to the landmarks in Fig. 1 and Table 1 for the dimension numbers in Table 3. 
Table 4 shows the morphometric measurements of the sectioned bodies of the fed and starved groups of rock bream and olive flounder, Paralichthys olivaceus. In rock bream the dimensions CIO, CIM, AO, AA, AM, THM, and WA increased in the fed group relative to the initial group, and no significant decrease was found for any morphometric dimension $(P<0.05)$. For the starved group the SS 2-1 dimension was significantly higher than in the initial and fed groups, but the values of most of the other dimensions in the starved group were significantly lower $(P<0.05)$. There were no significant differences among the three groups for the dimensions BS 1, BS 2, SS 3-1, SS 3-2, SS 3-3, and SS 4-1 (P>0.05).

In olive flounder the SL was significantly greater $(P<$

Table 4. Sectioned body characteristics of rock bream, Oplegnathus fasciatus, and olive flounder, Paralichthys olivaceus initial, fed and starved for 8 weeks

\begin{tabular}{|c|c|c|c|c|c|c|}
\hline Dimension & Initial group & Fed group & Starved group & Ratio 1 & Ratio 2 & Ratio 3 \\
\hline \multicolumn{7}{|c|}{ Rock bream } \\
\hline $\mathrm{SL}(\mathrm{cm})$ & $16.5 \pm 0.18^{\mathrm{a}}$ & $17.6 \pm 0.48^{\mathrm{a}}$ & $12.9 \pm 1.59^{b}$ & 1.06 & 0.78 & 1.36 \\
\hline $\mathrm{CIO}(\mathrm{cm})$ & $18.9 \pm 0.83^{b}$ & $20.9 \pm 0.84^{\mathrm{a}}$ & $14.5 \pm 1.15^{\mathrm{c}}$ & 1.11 & 0.77 & 1.44 \\
\hline CIA (cm) & $18.9 \pm 0.70^{\mathrm{a}}$ & $20.4 \pm 0.82^{\mathrm{a}}$ & $13.8 \pm 0.85^{\mathrm{b}}$ & 1.08 & 0.73 & 1.47 \\
\hline CIM (cm) & $15.5 \pm 1.24^{\mathrm{b}}$ & $18.1 \pm 1.25^{\mathrm{a}}$ & $12.2 \pm 0.82^{\mathrm{c}}$ & 1.17 & 0.79 & 1.48 \\
\hline $\mathrm{AO}\left(\mathrm{cm}^{2}\right)$ & $10.9 \pm 0.81^{b}$ & $14.4 \pm 0.89^{\mathrm{a}}$ & $5.1 \pm 0.47^{\mathrm{c}}$ & 1.32 & 0.47 & 2.80 \\
\hline $\mathrm{AA}\left(\mathrm{cm}^{2}\right)$ & $11.4 \pm 0.97^{\mathrm{b}}$ & $16.8 \pm 1.16^{\mathrm{a}}$ & $5.2 \pm 0.14^{\mathrm{c}}$ & 1.47 & 0.45 & 3.24 \\
\hline $\mathrm{AM}\left(\mathrm{cm}^{2}\right)$ & $7.1 \pm 0.62^{\mathrm{b}}$ & $11.3 \pm 0.96^{\mathrm{a}}$ & $3.3 \pm 0.20^{\mathrm{c}}$ & 1.61 & 0.46 & 3.47 \\
\hline THO $(\mathrm{cm})$ & $8.1 \pm 0.08^{\mathrm{a}}$ & $9.0 \pm 0.76^{\mathrm{a}}$ & $6.6 \pm 0.47^{\mathrm{b}}$ & 1.11 & 0.81 & 1.37 \\
\hline THA $(\mathrm{cm})$ & $8.3 \pm 0.41^{\mathrm{a}}$ & $9.0 \pm 0.54^{\mathrm{a}}$ & $6.5 \pm 0.54^{\mathrm{b}}$ & 1.09 & 0.78 & 1.39 \\
\hline THM (cm) & $7.4 \pm 0.50^{\mathrm{b}}$ & $8.5 \pm 0.65^{\mathrm{a}}$ & $5.9 \pm 0.45^{\mathrm{c}}$ & 1.16 & 0.80 & 1.45 \\
\hline $\mathrm{HO}(\mathrm{cm})$ & $3.2 \pm 0.06^{\mathrm{a}}$ & $3.6 \pm 0.48^{\mathrm{a}}$ & $2.6 \pm 0.17^{\mathrm{b}}$ & 1.11 & 0.81 & 1.36 \\
\hline WO (cm) & $2.7 \pm 0.04^{\mathrm{a}}$ & $3.0 \pm 0.32^{\mathrm{a}}$ & $1.6 \pm 0.18^{\mathrm{b}}$ & 1.12 & 0.59 & 1.90 \\
\hline WA (cm) & $2.5 \pm 0.14^{\mathrm{b}}$ & $2.9 \pm 0.18^{\mathrm{a}}$ & $1.4 \pm 0.16^{\mathrm{c}}$ & 1.13 & 0.53 & 2.12 \\
\hline $\mathrm{WM}(\mathrm{cm})$ & $1.8 \pm 0.29^{\mathrm{a}}$ & $2.2 \pm 0.22^{\mathrm{a}}$ & $0.9 \pm 0.05^{\mathrm{b}}$ & 1.24 & 0.49 & 2.54 \\
\hline BTO $1(\mathrm{~cm})$ & $0.3 \pm 0.06^{\mathrm{a}}$ & $0.4 \pm 0.07^{\mathrm{a}}$ & $0.2 \pm 0.02^{\mathrm{b}}$ & 1.31 & 0.66 & 2.00 \\
\hline BTO $2(\mathrm{~cm})$ & $0.2 \pm 0.03^{\mathrm{a}}$ & $0.2 \pm 0.02^{\mathrm{a}}$ & $0.1 \pm 0.03^{\mathrm{b}}$ & 1.17 & 0.70 & 1.66 \\
\hline $\mathrm{ABT}(\mathrm{cm})$ & $0.3 \pm 0.04^{\mathrm{a}}$ & $0.3 \pm 0.04^{\mathrm{a}}$ & $0.2 \pm 0.02^{\mathrm{b}}$ & 1.26 & 0.67 & 1.87 \\
\hline BS 1 & $114.4 \pm 4.44^{\mathrm{a}}$ & $116.2 \pm 1.54^{\mathrm{a}}$ & $107.8 \pm 9.79^{\mathrm{a}}$ & 1.02 & 0.94 & 1.08 \\
\hline BS 2 & $50.1 \pm 2.63^{\mathrm{a}}$ & $51.2 \pm 1.72^{\mathrm{a}}$ & $50.4 \pm 4.21^{\mathrm{a}}$ & 1.02 & 1.01 & 1.02 \\
\hline BS 3 & $15.4 \pm 0.99^{\mathrm{a}}$ & $16.4 \pm 1.31^{\mathrm{a}}$ & $10.7 \pm 2.29^{b}$ & 1.06 & 0.69 & 1.54 \\
\hline SS 1-1 & $33.1 \pm 0.50^{\mathrm{a}}$ & $33.4 \pm 2.64^{\mathrm{a}}$ & $24.1 \pm 1.88^{\mathrm{b}}$ & 1.01 & 0.73 & 1.39 \\
\hline SS $1-2$ & $30.8 \pm 2.43^{\mathrm{a}}$ & $32.1 \pm 3.52^{\mathrm{a}}$ & $21.2 \pm 4.04^{\mathrm{b}}$ & 1.04 & 0.69 & 1.52 \\
\hline SS 2-1 & $120.0 \pm 1.07^{\mathrm{b}}$ & $118.8 \pm 8.79^{\mathrm{b}}$ & $166.9 \pm 8.93^{\mathrm{a}}$ & 0.99 & 1.39 & 0.71 \\
\hline SS 3-1 & $9.4 \pm 1.18^{\mathrm{a}}$ & $10.9 \pm 2.57^{\mathrm{a}}$ & $11.0 \pm 2.40^{\mathrm{a}}$ & 1.15 & 1.16 & 0.99 \\
\hline SS 3-2 & $12.2 \pm 2.05^{\mathrm{a}}$ & $14.7 \pm 3.80^{\mathrm{a}}$ & $13.8 \pm 1.96^{\mathrm{a}}$ & 1.20 & 1.13 & 1.06 \\
\hline SS 3-3 & $6.7 \pm 0.99^{\mathrm{a}}$ & $7.1 \pm 1.46^{\mathrm{a}}$ & $8.2 \pm 3.02^{\mathrm{a}}$ & 1.06 & 1.23 & 0.86 \\
\hline SS 4-1 & $63.1 \pm 5.17^{\mathrm{a}}$ & $58.8 \pm 11.54^{\mathrm{a}}$ & $64.5 \pm 12.60^{\mathrm{a}}$ & 0.93 & 1.02 & 0.91 \\
\hline
\end{tabular}




\begin{tabular}{|c|c|c|c|c|c|c|}
\hline \multicolumn{7}{|c|}{ Olive flounder } \\
\hline $\mathrm{SL}(\mathrm{cm})$ & $16.6 \pm 0.45^{\mathrm{c}}$ & $28.7 \pm 0.99^{\mathrm{a}}$ & $18.7 \pm 0.95^{\mathrm{b}}$ & 1.72 & 1.12 & 1.53 \\
\hline $\mathrm{CIO}(\mathrm{cm})$ & $12.8 \pm 0.26^{\mathrm{c}}$ & $24.1 \pm 0.81^{\mathrm{a}}$ & $14.1 \pm 0.84^{\mathrm{b}}$ & 1.88 & 1.10 & 1.71 \\
\hline CIA $(\mathrm{cm})$ & $12.9 \pm 0.24^{\mathrm{c}}$ & $24.8 \pm 0.71^{\mathrm{a}}$ & $14.1 \pm 0.84^{\mathrm{b}}$ & 1.93 & 1.10 & 1.76 \\
\hline CIM $(\mathrm{cm})$ & $7.3 \pm 0.68^{\mathrm{c}}$ & $15.2 \pm 0.62^{\mathrm{a}}$ & $8.6 \pm 0.52^{b}$ & 2.10 & 1.18 & 1.77 \\
\hline $\mathrm{AO}\left(\mathrm{cm}^{2}\right)$ & $4.3 \pm 0.43^{\mathrm{a}}$ & $4.4 \pm 0.30^{\mathrm{a}}$ & $0.9 \pm 0.12^{\mathrm{b}}$ & 1.02 & 0.21 & 4.89 \\
\hline $\mathrm{AA}\left(\mathrm{cm}^{2}\right)$ & $5.1 \pm 0.24^{\mathrm{a}}$ & $5.5 \pm 0.43^{\mathrm{b}}$ & $1.1 \pm 0.14^{\mathrm{c}}$ & 1.08 & 0.22 & 5.00 \\
\hline $\mathrm{AM}\left(\mathrm{cm}^{2}\right)$ & $1.9 \pm 0.27^{\mathrm{b}}$ & $2.2 \pm 0.26^{\mathrm{a}}$ & $0.5 \pm 0.08^{\mathrm{c}}$ & 1.12 & 0.23 & 4.77 \\
\hline THO $(\mathrm{cm})$ & $6.3 \pm 0.17^{\mathrm{c}}$ & $11.3 \pm 0.39^{\mathrm{a}}$ & $6.8 \pm 0.40^{\mathrm{b}}$ & 1.79 & 1.08 & 1.65 \\
\hline THA (cm) & $6.5 \pm 0.16^{\mathrm{c}}$ & $11.6 \pm 0.32^{\mathrm{a}}$ & $6.8 \pm 0.41^{\mathrm{b}}$ & 1.79 & 1.05 & 1.71 \\
\hline THM (cm) & $3.6 \pm 0.36^{\mathrm{b}}$ & $4.3 \pm 0.20^{\mathrm{a}}$ & $4.1 \pm 0.22^{\mathrm{b}}$ & 2.01 & 1.14 & 1.76 \\
\hline $\mathrm{HO}(\mathrm{cm})$ & $2.8 \pm 0.19^{\mathrm{b}}$ & $4.9 \pm 0.30^{\mathrm{a}}$ & $2.9 \pm 0.21^{\mathrm{b}}$ & 1.74 & 1.01 & 1.72 \\
\hline WO (cm) & $1.3 \pm 0.10^{\mathrm{b}}$ & $2.6 \pm 0.14^{\mathrm{a}}$ & $1.1 \pm 0.07^{\mathrm{c}}$ & 1.92 & 0.85 & 2.27 \\
\hline $\mathrm{WA}(\mathrm{cm})$ & $1.1 \pm 0.05^{\mathrm{b}}$ & $2.3 \pm 0.13^{\mathrm{a}}$ & $0.9 \pm 0.06^{\mathrm{c}}$ & 2.06 & 0.81 & 2.56 \\
\hline $\mathrm{WM}(\mathrm{cm})$ & $0.8 \pm 0.05^{\mathrm{b}}$ & $1.7 \pm 0.08^{\mathrm{a}}$ & $0.7 \pm 0.09^{c}$ & 2.18 & 0.88 & 2.49 \\
\hline BTO 1 (cm) & $0.6 \pm 0.11^{\mathrm{c}}$ & $1.4 \pm 0.23^{\mathrm{a}}$ & $0.8 \pm 0.09^{\mathrm{b}}$ & 2.31 & 1.36 & 1.70 \\
\hline BTO $2(\mathrm{~cm})$ & $0.2 \pm 0.05^{\mathrm{b}}$ & $0.3 \pm 0.05^{\mathrm{a}}$ & $0.1 \pm 0.05^{\mathrm{b}}$ & 2.30 & 0.92 & 2.51 \\
\hline $\mathrm{ABT}(\mathrm{cm})$ & $0.4 \pm 0.07^{\mathrm{c}}$ & $0.9 \pm 0.12^{\mathrm{a}}$ & $0.5 \pm 0.05^{\mathrm{b}}$ & 2.31 & 1.28 & 1.81 \\
\hline BS 1 & $77.3 \pm 2.61^{\mathrm{b}}$ & $86.6 \pm 2.46^{\mathrm{a}}$ & $75.3 \pm 1.51^{b}$ & 1.12 & 0.98 & 1.15 \\
\hline BS 2 & $39.1 \pm 1.83^{\mathrm{a}}$ & $40.5 \pm 1.32^{\mathrm{a}}$ & $36.3 \pm 0.81^{b}$ & 1.04 & 0.93 & 1.11 \\
\hline BS 3 & $6.8 \pm 0.47^{\mathrm{b}}$ & $8.1 \pm 0.52^{\mathrm{a}}$ & $4.9 \pm 0.23^{\mathrm{c}}$ & 1.20 & 0.72 & 1.67 \\
\hline SS 1-1 & $21.3 \pm 1.41^{\mathrm{b}}$ & $22.9 \pm 1.21^{\mathrm{a}}$ & $16.7 \pm 1.25^{\mathrm{c}}$ & 1.08 & 0.79 & 1.37 \\
\hline SS 1-2 & $17.4 \pm 0.43^{\mathrm{b}}$ & $20.1 \pm 0.93^{\mathrm{a}}$ & $13.4 \pm 0.45^{\mathrm{c}}$ & 1.16 & 0.77 & 1.50 \\
\hline SS 2-1 & $211.1 \pm 15.74^{\mathrm{b}}$ & $190.9 \pm 13.88^{\mathrm{c}}$ & $251.4 \pm 3.49^{\mathrm{a}}$ & 0.90 & 1.19 & 0.76 \\
\hline SS 3-1 & $28.2 \pm 4.72^{\mathrm{c}}$ & $33.9 \pm 4.83^{\mathrm{b}}$ & $42.4 \pm 5.03^{\mathrm{a}}$ & 1.20 & 1.50 & 0.80 \\
\hline SS 3-2 & $45.4 \pm 8.43^{\mathrm{b}}$ & $54.5 \pm 9.60^{\mathrm{b}}$ & $72.9 \pm 10.13^{\mathrm{a}}$ & 1.20 & 1.61 & 0.75 \\
\hline SS 3-3 & $11.1 \pm 2.45^{\mathrm{a}}$ & $13.3 \pm 1.67^{\mathrm{a}}$ & $12.0 \pm 3.93^{\mathrm{a}}$ & 1.20 & 1.08 & 1.12 \\
\hline SS 4-1 & $68.8 \pm 5.80^{c}$ & $248.2 \pm 8.54^{\mathrm{b}}$ & $276.7 \pm 20.01^{\mathrm{a}}$ & 3.59 & 4.01 & 0.90 \\
\hline
\end{tabular}

The values are means \pm SD (rock bream: $n=10$, olive flounder: $n=30$ ) of triplicated groups respectively. Means in rows with a same superscript letter are not significantly different $(P>0.05)$. Abbreviations (Figs. 2 and 3), SL: standard length; CIO: body circumference at one-third line between most posterior aspect of operculum and mediate point of standard length; CIA: body circumference at a vertical line which intersects at right angle with the intermediate point of standard length; CIM: body circumference at midpoint line between mediate point of standard length and most posterior scale in lateral line; AO: area on section at one-third line between most posterior aspect of operculum and mediate point of standard length; AA: area on section at a vertical line which intersects at right angle with the intermediate point of standard length; AM: area on section at midpoint line between mediate point of standard length and most posterior scale in lateral line; THO: total height on section at one-third line between most posterior aspect of operculum and mediate point of standard length; THA: total height on section at a vertical line which intersects right angle with the intermediate point of standard length; THM: total height on section at midpoint line between mediate point of standard length and most posterior scale in lateral line; HO: height on section at one-third line between most posterior aspect of operculum and mediate point of standard length; WO: width on section at one-third line between most posterior aspect of operculum and mediate point of standard length; WA: width on section at a vertical line which intersects at right angle with the intermediate point of standard length; WM: width on section at midpoint line between mediate point of standard length and most posterior scale in lateral line; BTO 1: belly thickness 1 on section at one-third line between most posterior aspect of operculum and mediate point of standard length; BTO 2: belly thickness 2 on section at one-third line between most posterior aspect of operculum and mediate point of standard length; ABT: average belly thickness, (BTO 1+BTO 2)/2; BS 1: body shape 1, (CIA/SL) $\times 100$ BS 2: body shape 2, (THA/SL) $\times 100$; BS 3: body shape 3, (WA/SL) $\times 100 ;$ SS 1-1: section shape $1-1$, (WO/THO) $\times 100$; SS 1-2: section shape 1-2, (WA/THA) $\times 100$; SS 2-1: section shape 2-1, (HO/WO $\times 100$; SS 3-1: section shape 3-1, $(\mathrm{ABT} / \mathrm{WO}) \times 100$; SS 3-2: section shape 3-2, (BTO 1/WO) $\times 100$; SS 3-3: section shape 3-3, (BTO 2/WO) $\times 100$; SS 4-1: section shape 4-1, $[0.5(\pi \times \mathrm{HO} \times 0.5 \times \mathrm{WO}) / \mathrm{AO}] \times 100$; Ratio 1: fed group/initial group; Ratio 2: starved group/initial group; Ratio 3: fed group/starved group. 
0.05) in the fed group compared with the control group (1.72-fold) and the starved group (1.53-fold). The values for body circumference, section area, section height, and section width were significantly higher $(P<0.05)$ in the fed group than in the initial and starved groups. Relative to the initial group, the body circumference value in the starved group was higher but the section area and width values were lower $(P<0.05)$. The values for BTO 1, BTO 2 and ABT related to abdominal cavity thickness were higher in the fed group than in the starved group $(P<0.05)$. The SS 1-1, SS 1-2, and SS 2-1 morphometric dimensions are related to body width and body height. The value of SS 2-1 was significantly higher in the starved group relative to the fed and initial groups $(P<0.05)$, while the values of SS 3-1, SS 3-2, and SS 4-1 were higher in the starved group relative to the fed group $(P<0.05)$.

Rations 1(fed group/ initial group) of all dimensions on rock bream were lower than those on olive flounder. That is, growth of olive flounder was faster than rock bream. Ration 2 (starved group/initial group) of all dimensions on rock bream were below 1.0, respectively. Ration 2 of AO, $\mathrm{AA}$ and $\mathrm{AM}$ on rock bream were higher than those on olive flounder. Rations 2 of SL, CIO, CIA, CIM, THO, THA and THM on rock bream were lower than those on olive flounder. In addition, rations 2 of the other dimensions on rock bream were lower than those on olive flounder. Rations 3 (fed group/ staved group) of all dimensions on olive flounder were higher than rock bream. In other words, difference of morphometric characteristic between fed alnd starved group on olive flounder was higher than rock bream. Therefore, effects of starvation on rock bream were more noticeable than those on olive flounder.

\section{DISCUSSION}

At completion of the eight-week experimental period specimens of rock bream, Oplegnathus fasciatus, the SL and BW had increased in the fed group, but these para- meters had decreased in fish in the starved group $(P<$ 0.05). In particular, the loss of BW in the starved group was more precipitous $(P<0.05)$. In olive flounder, Paralichthys olivaceus, the SL and BW also increased in the fed group $(P<0.05)$, but decreased in the starved fish (Park et al., 2006). Thus, in both species decreased growth was evident in the starvation group, which is similar to the results obtained by Sumpter et al. (1991) during four-week starvation experiment involving rainbow trout, Oncorhynchus mykiss. During a 12-week starvation experiment involving olive flounder, Park et al. (2006) reported growth inhibition in starved fish was evident in the condition factor, specific growth rate, growth rate as a function of BW, and GW. An increase in the DP of starved fish has been attributed to a decrease in the VW. Park et al. (2006) reported that in olive flounder the DP in starved fish increased but the VW decreased. They found that the fed group had significantly greater weight, GW, and VW compared with the starved group, but the two groups were not significantly different with respect to the VI. This was because of the relatively high VI according to energy consumption for accumulating primary muscles by starving in the starved group, and this energy consumption caused a decrease in weight in the starved group (Park et al., 2006).

In the starved group the truss dimensions $1 \times 2,1 \times 9$, $1 \times 10,4 \times 5,4 \times 6$, and $5 \times 6$, and the classical dimensions $1 \times 2$, $1 \times 3,1 \times 5,1 \times 10$, and $1 \times 12$ increased in rock bream $(P<$ 0.05). These results are indicative of the decrease in SL in the starved group. The head connection morphometric analysis showed increases in both truss and classical dimensions in the starved group, but the classical dimensions decreased in the fed group $(P<0.05)$. Classical and truss dimensions in the head region have also been reported to increase significantly in Chinese minnow, Rhynchocypris oxycephalus during nine weeks of starvation (Park et al., 2001). According to Park et al. (2007) there were significant decreases in classical head dimensions in a fed group of olive flounder, while in a starved group there were significant decreases in 
classical dimensions in relation to the anterior-posterior body axis. This is inconsistent with the observation of Currens et al. (1989), who reported that while the truss dimensions of the head were generally large in rainbow trout and chinook salmon, O. tshawytscha under various feeding regimes, the trunk dimensions were smaller (Park et al., 2007). In rock bream the trunk region dimensions, including a large component of body depth, are likely to be variable because of differences in the feeding regimes of fish in differing habitats. In olive flounder the truss dimensions for almost the entire trunk region increased significantly in the fed group, while in the starved group the dimensions of the trunk region in relation to body depth decreased significantly (Park et al., 2007). In the Chinese minnow study noted above (Park et al., 2001), both the truss and the classical head and trunk region dimensions were generally affected in fed or starved fish, and it was hypothesized that physiological changes in fat metabolism could explain the differences observed between the fed and starved fish. These results are similar to those reported by Theilacker (1978), who noted that body shape dimensions, especially body depth, reflected nutritional conditions (Park et al., 2001). In another study, Currens et al. (1989) suggested that the trunk region was the site of greatest fat deposition and loss during periods of feeding and fasting in salmonid fish.

Dimensions that did not significantly differ among all three feeding regimes were the truss dimensions $1 \times 8,2 \times 3$, $2 \times 7,2 \times 8,2 \times 9,3 \times 5,3 \times 6,3 \times 7$, and $6 \times 7$, and the classical dimensions $1 \times 7,1 \times 8,1 \times 11$ and $6 \times 7(P>0.05)$. These results indicate that these body parts are less likely to be affected by food availability or quality. Similar results were reported for morphometric characteristics in olive flounder (Park et al., 2007). Thus, these truss and classical dimensions may be useful taxonomic features for discriminating species of rock bream and olive flounder. Previous studies have used caudal region dimensions in salmonid fry, and other truss and classical dimensions in
Chinese minnow, as taxonomic indicators (Currens et al., 1989; Park et al., 2001).

In rock bream and olive flounder the fed group generally exhibited higher values for body circumference parameters, including cross-cut sectional area and total height, compared with these dimensions in the starved group $(P<0.05)$. Most of these parameters were also smaller in the starved group than in the initial group $(P<0.05)$. Body height and truss dimensions have previously been determined in feeding and starvation experiments (Park et al., 2007). Significant changes were observed in the ' $\mathrm{A}$ ' and ' $\mathrm{M}$ ' line regions in terms of total height and area in relation to body circumference, relative to the ' $O$ ' line region. The trunk is the most likely region to show changes resulting from feeding or starvation. Park et al. (2002) attribute the thinness of the abdominal cavity in starved fish to fasting-induced endogenous absorption of energy from this region. As thicker fish are more profitable from a commercial standpoint (Gjerde \& Schaeffer, 1989), starved fish will inevitably be of lower value. Park et al. (2002) suggested that during starvation phenotypic variation occurs firstly in dorsal fins of the abdominal region and secondly in pectoral fins. This is similar to the report of Lee et al. (1998), who noted that the primary impact of starvation in Chinese minnow was evident in the abdominal area. Park et al. (2001) also noted that the upper body truss dimension and the body depth classical dimension decreased significantly in starved Chinese minnow. The morphometric dimensions SS 1-1, SS 1-2, and SS 2-1 in two species are related to body width and body height. The results of this experiment showed that the cross-cut section of the fed group was more circular than that of the starved group. This characteristic is an indication of high commercial value (Gjerde \& Schaeffer, 1989).

The study has conducted on effect of starvation until now. Hur et al. (2006a) reported the effects of nutritional conditions on changes in condition factor, liver somatic index, and hepatocyte ultrastructure in the olive flounder. Hur et al. (2006b) also investigated the influence of nutritional 
conditions on histological changes in melano-macrophage accumulation in the kidney, caused by long-term starvation. During starvation, essential processes in fish are maintained at the expense of accumulated energy reserves, resulting in the progressive depletion and wastage of body tissues. Therefore, studies of fish nutrition in relation to growth and condition can increase understanding of the responses of wild and cultured fish to feed conditions (Weatherley \& Gill, 1987; Lee et al., 1998; Park et al., 1998; Park et al., 2001). Analysis of the various dimensions investigated in this study has been shown to provide an accurate indication of the nutritional condition of other fish.

\section{ACKNOWLEDGEMENTS}

This research was funded through Project 2010-0021293 of the National Research Foundation of Korea, Korea. We are grateful to the staff of the Fishery Genetics and Breeding Science Laboratory of the Korea Maritime and Ocean University, Korea. This manuscript was improved by comments from anonymous reviewers. All of the experiments performed in this study complied with the current laws of Korea (the Law Regarding Experimental Animals, No. 9932) and the Ethical Guidelines of Korea Maritime and Ocean University, Korea.

\section{REFERENCES}

Choi Y, Kim JH, Park JY (2002) Sea Fish in Korea. KyoHak Publish. Co., Seoul, Korea, p. 384.

Currens KP, Sharpe CS, Hjort R, Schreck CB, Li WH (1989) Effect of different feeding regimes on the morphometrics of chinook salmon (Oncorhynchus tshawtscha) and rainbow trout (O. mykiss). Copeia 3:689-695.

Duncan DB (1955) Multiple-range and multiple F tests. Biometrics 1:1-42.

Gjerde B (1989) Body traits in rainbow trout: Phenotypic means and standard deviation and sex effects. Aquaculture $80: 7-24$

Gjerde B, Schaeffer LR (1989) Body traits in rainbow trout. II. estimates of heritabilities and of phenotypic and genetic correlations. Aquaculture 80:25-44.

Hubbs CL, Lagler KF (1947) Fishes of the Great Lakes region. Cranbrook Inst Sci Bull 26:1-186.

Humphries JM, Bookstein FL, Chernoff B, Smith GR, Elder RL, Poss SC (1981) Multivariate discrimination by shape in relation to size. Syst Zool 30:291-308.

Hur JW, Jo JH, Park I-S (2006a) Effects of long-term starvation on hepatocyte ultrastructure of olive flounder, Paralichthys olivaceus. Ichthyol Res 53:306-310.

Hur JW, Woo SR, Jo JH, Park I-S (2006b) Effects of starvation on kidney melano-macrophage centre in olive flounder, Paralichthys olivaceus (Temminck and Schlegel). Aquacult Res 37:821-825.

Ihssen PE, Booke HE, Casslman JM, McGlade JM, Payne NR, Utter FM (1981) Stock identification: materials and methods. Can J Fish Aquat Sci 38:1838-1855.

Lee CK, Park I-S, Hur SB (1998) Influence of starvation on the variations of hepatocyte nucleus in larvae of red spotted grouper, Epinephelus akaara. J Aquacult 11: $11-17$.

Lee K-K, Kim YH, Park I-S (1999) Effect of starvation on some nutritional parameters in Rhynchocypris oxycephalus.

1. Characteristics of the histological and biochemical changes. Korean J Ichthyol 11:33-41.

Mustafa S, Mittal A (1982) Protein, RNA and DNA levels in liver and brain of starved, catfish, Clarias batrachus. J Ichthyol 28:396-400.

Park I-S (2006) Histological changes of hepatocyte and intestinal epithelium during starvation in olive flounder, Paralichthys olivaceus. J Korean Fish Soc 39:303-307.

Park I-S, Hur JW, Choi JW (2012) Hematological responses, survival, and respiratory exchange in the olive flounder, Paralichthys olivaceus, during starvation. Asian-Aust J 
Anim Sci 25:1276-1284.

Park I-S, Im JH, Jeong CH, Noh JK, Kim YH, Lee YH (2002) Effect of starvation on some nutritional parameters in Rhynchocypris oxycephalus (Sauvage and Dabry). 2. Characteristics of the morphometric changes in the sectioned body. Korean J Ichthyol 14:11-18.

Park I-S, Im JM, Ryu DK, Nam YK, Kim DS (2001) Effect of starvation on morphometric changes in Rhynchocypris oxycephalus (Sauvage and Dabry). J Appl Ichthyol 17: 277-281.

Park I-S, Lee CK, Im JH, Kim JH, Kim SU (1998) Effect of starvation on the growth and hepatocyte nuclear size of larval rockfish Sebastes schlegeli and larval spotted sea bass Lateolabrax sp. J Aquacult 11:345-352.

Park I-S, Woo SR, Kim EM, Cho SH (2006). Effect of feeding and starvation on growth and phenotypic traits in olive flounder, Paralichthys olivaceus (Temminck et Schlegel). J Aquacult 19:183-187.

Park I-S, Woo SR, Song YC, Cho SH (2007) Effects of starvation on the morphometric characteristics of olive flounder Paralichthys olivaceus. Ichthyol Res 54:297302.

Riddell BE, Leggett WC, Saunders RL (1981) Evidence of adaptive polygenic variation between two populations of Atlantic salmon (Salmo salar) native to tributaries of the S. W. Miramichi River. N. B. Can J Fish Aquat Sci 38:321-333.

Seol D-W, Hur JW, Kim DS, Nam YK, Bang IC, Park I-S
(2009) Effect of starvation on kidney melano-macrophage centre in sub-adult rock bream, Oplegnathus fasciatus. J Fish Sci Technol 12:49-53.

Straüss RE, Bookstein FL (1982) The Truss: body from reconstructions in morphometrics. Syst Zool 31:113135.

Sumpter JP, Le Bail PY, Pickering AD, Pottinger TG, Carragher JF (1991) The effect of starvation on growth and plasma growth hormone concentrations of rainbow trout, Oncorhynchus mykiss. Gen Comp Endocr 83: 94-102.

Sun Z-Z, Liu X-Z, Xu Y-J, Li J, Qu J-Z, Lan G-G, Liang F (2009) Effects of starvation on the growth and development of larval and juvenile rock bream, Oplegnathus fasciatus. Mar Fish Res 30:8-13.

Taylor EB, McPhail JD (1985) Variation in burst and prolonged swimming performance among British Columbia populations of coho salmon (Oncorhynchus kisutch). Can J Fish Aquat Sci 42:2029-2033.

Theilacker GH (1978) Effect of starvation on the histological and morphological characteristics of jack mackerel, Trachurus symmetricus, larvae. Fish Bull 76:403-414.

Weatherley AH, Gill HS (1987) The Biology of Fish Growth. 4. Protein, Lipid and Caloric Contents. Academic Press, London, pp. 139-146.

Winans GA (1984) Multivariate morphometric variability in Pacific salmon: Technical demonstration. Can J Fish Aquat Sci 41:1150-1159. 